\title{
THE EFFECTS OF SUSTAINABILITY REPORT DISCLOSURE ON PRODUCT LIFECYCLE MANAGEMENT PRACTICES TOWARDS SUSTAINABILITY PERFORMANCE: A STUDY ON INDONESIAN PULP AND PAPER INDUSTRY
}

\author{
Mohd Haizam Mohd Saudi ${ }^{*}$, Deden Sustina ${ }^{2}$, Anne Nurfarina ${ }^{3}$, Diana Sari ${ }^{4}$, Obsatar Sinaga ${ }^{5}$ \\ ${ }^{1}$ Faculty of Business and Law, International University of Malaya-Wales, Kuala Lumpur, Malaysia \\ ${ }^{2}$ Faculty of Business and Management, Widyatama University, Bandung, Indonesia \\ ${ }^{3}$ Faculty of Design and Visula Communication, Widyatama University, Bandung, Indonesia \\ ${ }^{4}$ Faculty of Economy, Widyatama University, Bandung, Indonesia \\ 5 Department of International Relations, Padjadjaran University, Bandung, Indonesia \\ *haizam@iumw.edu.my
}

\begin{abstract}
Life-cycle management practices have become an important subject in the business world today. The business world, especially in the pulp and paper industry has engaged in the disclosure of the sustainability report for the reference of the stakeholders. The stakeholders are concern on the business growth of the organization and understood the facts that financial statement alone would not be sufficient, but it is also vital for companies to analyze the economic, social and environmental aspects of the company's operations. 70 companies from paper and pulp industries in Indonesia were being tested using primary data. The research found that sustainability report disclosure has created a significant impact towards products lifecycle management practices in enhancing sustainability performance. The sustainability report has been found to enhance the productivity of the employees and create a sense of confident and loyalty amongst the investors in order to created good image of the organizations particularly in the pulp and paper industry in Indonesia.
\end{abstract}

Keywords: Product Lifecycle Management Practices, Lean Management Practices, Sustainability Report, Sustainability Performance

\section{INTRODUCTION}

The transition on way of reporting financial aspects in recent years have been shifted tremendously whereby many organizations started to shift from traditional way of reporting financial aspects, transformed into modern reporting in all aspects, both financial and non-financial (social and environmental dimensions) to the stakeholders (Tarigan \& Semuel, 2015). Sustainability report is one of the non-financial reports which issued in company or organization describing the economic, environmental and social impacts caused by daily activities of the firm (Labuschagne et al., 2005). Sustainability report helps organizations to measure and understand the performance of economic, environmental, and social, and subsequently set goals and manage change more effectively (Lozano et al., 2016). Sustainability reports could be considered synonymous with non-financial reporting terms, triple bottom line reporting and CSR reporting (Tarigan \& Semuel, 2015). In 2002, the Indonesian government has disseminated information to industry players urged timber companies, wood processers and paper manufacturers to pay attention to availability, stability of natural resources and to improve their productivity in various aspects. Based on demand market pressure, the sustainability report publication has become a trend, one of which is encouraged by the annual award for sustainability report initiated by National Centre for Sustainability Reporting (NCSR) (Tarigan \& Semuel, 2015). Furthermore, the increasing demands of stakeholders encourage companies to provide information that are transparent, accountable and good corporate governance practices (Lozano et al., 2016).

Sustainability reports have been emphasised not only in Indonesia, but also in developing country such as Malaysia. In a previous study, Malaysia International Chamber of Commerce and Industry (MICC) 
presented environmental awards to environmental awareness organizations because they have shown their environmental concern that will enhance the company's reputation indirectly (Sawani et al., 2010).

Regulations in Indonesia on sustainability reporting (SR) set out in Regulation, (Number 40 Year 2007) regarding liability companies was passed in July 2007 (Tarigan \& Semuel, 2015). This legislation mandates the entire liability companies whose business activities related to natural resources to carry out the environmental social responsibility (Labuschagne et al., 2005; Mukherjee \& Sovacool, 2014), as well as presenting information about the performance of activities of the environmental social responsibility in the annual report (Mukherjee \& Sovacool, 2014). The new phenomenon that occurred in Indonesia saw the number of companies that disclose sustainability report has increased in the past years, which started only one company in 2005 (Budiman \& Supatmi, 2009) and increased to eighty companies in 2015 (Lozano et al., 2016) even when the requirement of disclosure of sustainability report by Indonesian regulatory is still voluntary (Budiman \& Supatmi, 2009). This provides an understanding that companies already have a concern on disclosure of sustainability report that related to economic, environmental, and social sustainability. Pulp and paper industry is one of the few industries in Indonesia which have high competitiveness and excellence (competitive advantage) (Gritten \& Kant, 2007; Hajmohammad et al., 2013; Piercy \& Rich, 2015) that it can dominate the world market (Piercy \& Rich, 2015). However, problem arises when some companies have yet to realize the commitment to support their sustainability development (Labuschagne et al., 2005; Lozano et al., 2016).

\section{Problem Statement}

Companies around the world have tried to eliminate various activities that create unnecessary costs (Alpenberg \& Scarbrough, 2016). The activities that are not needed will be eliminated and the improvement of the efficiency of the activities would be enhanced (Piercy \& Rich, 2015; Ngoc \& Schnitzer, 2009). In the previous study, the consumption of resources and usage of high cost to produce the output has been identified. Thus, the consumption of resources would be minimized and the product could provide an added value to the customers (Piercy \& Rich, 2015). The main concern of the industry is the pollution created by the manufacturer and thus, gives a bad impression in the eye of the stakeholders. The pulp industry has been found polluting the Indonesian river where the dumping of waste caused pollution to the nature and hazardous to the community (Vila et al., 2015). Hence, this will have a direct impact on the company's performance both in economic and environmental value (Piercy \& Rich, 2015).

A comprehensive life cycle management (LCM) approach is eventually required (Eigner et al., 2017), which assures that operational methods are consistent and there is effective sharing and coordination of resources, records and technology. In a previous research, LCM significantly affects the performance of the companies (Eigner et al., 2017; Zhang et al., 2014) and also sustainability performance. However, in some conditions, previous study also found that there are many companies produce waste that is reducing the company's performance and the performance of sustainability by creating a large quantity of wastages (Eigner et al., 2017). There are several things that can be raised through sustainability report has not been considered which would help organizations to measure and understand the performance of economic, environmental, and social (Zhang et al., 2014; Freeman, 2010; Seuring \& Gold, 2013). Hence, the companies would be able to set goals and manage change more effectively by implementing lifecycle management practices (Duque Ciceri et al., 2009). Green product lifecycle must be taken into consideration in this crucial stage as it would curb the mismanagement of the liquid and solid wastes (Eigner et al., 2017). The real problem is to translate this approach in the private sector and the responsibility of public studies organization is to promote movements to construct the preliminary blocks for changing the organization culture and define concrete actions (Seuring \& Gold, 2013). The need of new technology to optimize the resources is impeccable (Gritten \& Kant, 2007; Hajmohammad et al., 2013).

\section{THEORETICAL BACKGROUND Stakeholder Theory}


Stakeholder theory is one of the main theories that are widely used for the underlying research on the sustainability report. The initial basic thought about the stakeholder theory proposed by Freeman (2010). According to Freeman (2010), exerted that a stakeholder approach suggests that managers should formulate and implement a process that is satisfying and only to those groups who have an interest in business.

In addition, the company is also expected to meet the interests of stakeholders as parties that influence the company's operations (Freeman, 2010). Therefore, a company that does the disclosure sustainability report taking into accounts the interests of stakeholders. Thus, it will have an impact on the achievement of the company's performance (Lozano et al., 2016; Seuring \& Gold, 2013; Elkington, 1997). Therefore, when the company achieved good performance, the company could achieve success and competitive advantage in the long term.

\section{Product Lifecycle Management}

The sustainable development subjects through collaboration and cooperation among organization is vital, permitting the organization to be more resource-green. Hence, through this collaboration, the employer may be a "green" or "ecological driven" organization (Eigner et al., 2017), not only in product design but also in production-manufacturing and in product give up life cycle (Duque Ciceri et al., 2009), which means the entire product is concerned in product improvement (Freeman, 2010; Seuring \& Gold, 2013). Control and management of all data and processes associated with the product or service throughout its product life cycle (from the design phase to turnover and consumption by consumers) (Srinivasan, 2011; Duque Ciceri et al., 2009; Zhang et al., 2014).

PLM brings together all single applications that support the product creation process. Currently, the manufacturing and services industries face challenges and competition is very intense (Eigner et al., 2017; Freeman, 2010). Product life cycles are getting shorter, the products are more varied and customized, competitors increasingly competitive, tighter regulation and operations that cover a wide range of countries makes the need for a system that is able to manage the pile of data from each stage of supply chain of the product and services through supporting applications become very important (Eigner et al., 2017; Freeman, 2010). Based on critical of PLM (1) maturity of standardized product information and meta-records models, and standardized engineering and enterprise methods; (2) The emergence of provider-oriented architecture for information sharing; and (3) the availability of a robust middle-ware to implement them (Eigner et al., 2017; Duque Ciceri et al., 2009; Freeman, 2010).

Researchers also discussed the reasons on the need of product development practices and knowledge control in the organization (Zhang et al., 2014; Freeman, 2010). In previous research, coping with PLM from a more conceptual perspective were discussed, rather than the function of knowledge management within the aggressive fulfilment of companies (Zhang et al., 2014). Furthermore, no matter how unique lifecycle knowledge management helps tactics, its underlying goal is always to fulfil the mission and vision of the organization.

\section{Sustainability Report Disclosure}

According to Global Reporting Initiative (GRI) (2016a), sustainability report means a report containing financial performance information and also provide non-financial information consists of information about social and environmental activities which enable the company to grow continuously (sustainable performance). Meanwhile, according to (Milne \& Gray, 2013; Freund, 2005), sustainability report is a sustainability report issued by a company or organization on the impact of economic, environmental and social caused by everyday activities. Sustainability report is a general term that is similar with other terms such as the triple bottom line report. The term was first popularized by GRI (2016a), which explains that the company that wants to be noticed via 3P sustainable. In addition to the pursuit of profit (profit), the company must be involved in the fulfilment of public welfare (people), and contribute to protecting the environment (planet) (Lee \& Sabharwal, 2016; GRI, 2016b). Sustainability report is a form of sustainability reporting developed by the GRI. GRI is an independent agency established in 1997 in Boston, USA with a multi-professional membership such as accountants, entrepreneurs, investors, environmental organizations, human rights organizations, research institutions and labour organizations of various countries (Elkington, 1997; Lee 
\& Sabharwal, 2016; Fogliasso \& Deeds, 2012; Chin, 1998). GRI stands because of the increasingly urgent transparency of the business activities of the company's economic, environmental and social activities so that it needs guidance to prepare sustainability report for companies in various sizes and business sectors around the world (Lozano et al., 2016; GRI, 2016a; Milne \& Gray, 2013).

\section{Sustainability Performance}

Sustainability performance could be defined as performance that being measured not only by financial impact but also related directly with the social, economic and operation within the organization environment internally and externally. The sustainability performance is vital for the organization to maintain the level of confidence amongst the investors. The image of the organization would be enhanced through the steady sustainability performance over a long period of time (Govindan et al., 2014). Thus, it would be beneficial to the organization to maintain the sustainability performance because it would boost its image and reputation in the eye of the stakeholders.

The hypothesis in this research states that:

H1: There is a positive significant relationship between product life cycle management practices and sustainability performance (SP) mediated by Disclosure of Sustainability Report in Indonesian pulp and paper industry.

\section{METHODOLOGY}

As shown in Figure 1, the proposed the hypothesized measurement model this study examines the extent to which Product Lifecycle Management Practices affect sustainability performance. We investigate the effect of sustainability report disclosure as mediating variable towards sustainability performance with Smart PLS 3.0 Software.

Systematic random sampling the sampling frame is first, divided into a number of segments called intervals. Then, from the first interval, using the SRS technique, one element is being selected. In this research, a systematic random sample relies on some sort of ordering to choose sample all selected manager from each region consist of 70 companies from pulp and paper industries. The selection of subsequent elements from other intervals is dependent upon the order of the element selected in the first interval. This random sampling use because eliminates bias by giving all individuals an equal chance to be chosen. Conceptualization Model is the first step in PLS-SEM analysis.

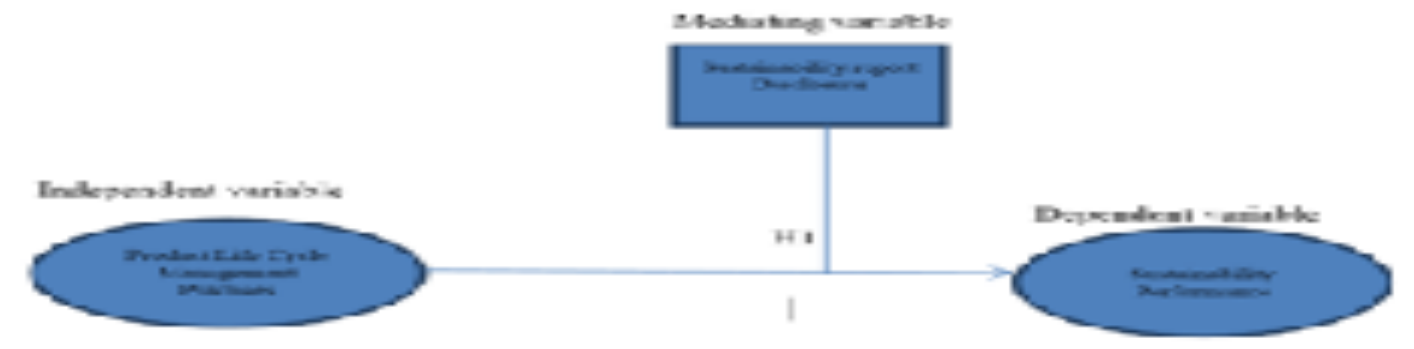

Figure 1. Conceptual framework

For the current study, Likert scales is used to measure the responses, since this scale is widely used in product lifecycle practices research and has been extensively tested in social science. The present study used a seven-point Likert scales for measuring all variables in this study. All of their comments and suggestions regarding the clarity, relevance (content/face validity) and consistencies of the questions incorporated into the survey instrument.

\section{RESULTS AND DISCUSSION}

\section{Finding and Analysis}

The researcher evaluates the PLS model based on the prediction orientation that has non-parametric properties. The researcher considers that the PLS evaluation model as shown in Figure 2 proposed the final hypothesized 


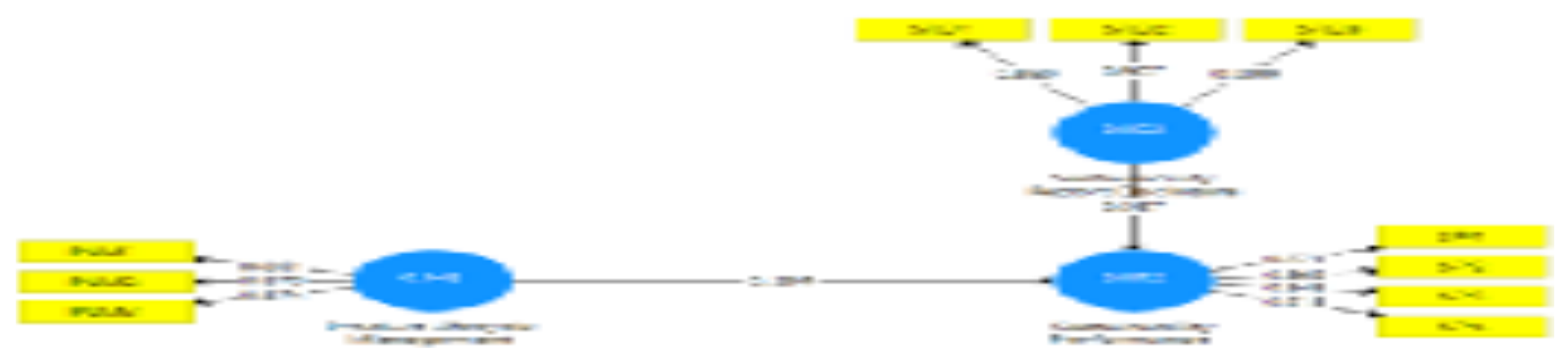

Figure 2. PLS-SEM model

We investigate the impact of PLM variables on Sustainability Performance (SP) and Sustainability Report Disclosure (SRD) as a mediating pathway. There are 248 usable respondents for data analysis and model validation for this research. The researcher analyses that in Indonesian pulp and paper industry, Product Lifecycle Management Practices (PLM) have a positive significant impact on its sustainability performance (SP).

The researcher considers that the PS evaluation model is performed for a "measurement model" or outer model to assess the validity and reliability of the model. The outer model in this study uses reflexive indicators by evaluating through convergent and discriminant validation of latent construct and composite reliability formers and Cronbach alpha for its indicator block (Hair et al., 2012; Wang et al., 2010).

By using product indicator (mediating variables SRD) the coefficient path value is increasing from 0.284 to 0.537 and has significant effect to sustainability performance because the value of T-Test $>$ 1.96 (Fornell \& Larcker, 1981) as shown Table 1. It could be explained that the relationship between PLM and SP would be enhanced with the mediation by SRD.

Independent Variable: Product Life Cycle Management (PLM)

Dependent Variable: Sustainability Performance (SP)

Mediating Variable: Sustainability Report Disclosure (SRD)

Table 1. T-statistic value, interaction effect of product indicator approach

\begin{tabular}{|c|c|c|c|}
\hline Relation & Path Coefficients & T Statistics & Remark \\
\hline LPM -> SP & 0.284 & 4.757 & No Product Indicators \\
\hline LPM -> SP \& SRD & 0.537 & 4.533 & Product Indicators \\
\hline
\end{tabular}

The analysis reveals that in Indonesian pulp and paper industry, lean management practices enhance sustainability performance on product lifecycle management has an effect interaction in the structural model.

The discriminant validity test conducted by comparing the square root of AVE for each construct with the correlation value between constructs in the model. Good discriminant validity shown on the square root of AVE for each construct is greater than the correlation between the constructs in the model. Hair et al. (2012) expresses the rule of thumb reliability value that the use of Cronbach Alpha to test the reliability of the constructs will give lower value (under estimate), so it is preferable to use composite reliability should be greater than $0.60-0.70$ is still acceptable for exploratory research adopted from Hair et al. (2012) and Wang et al. (2010). Discriminant validity test resulted from model structure examined that composite reliability of PLM (0.900); SRD (0.924); and SP (0.945), means that all constructs in the model structure can be considered to have good reliability because they are more than 0.70 as shown in Table 2 .

The next step in analysing the structure of the model Rule of thumb for the recommended AVE value must be greater than 0.50 and each cross loading for each variable in the measurement model $(>0.70)$ means that $50 \%$ or more variance of the indicator could be explained. 
The Turkish Online Journal of Design, Art and Communication - TOJDAC

ISSN: 2146-5193, September 2018 Special Edition, p.866-873

Table 2. Loading factor with SmartPLS 3

\begin{tabular}{|c|c|c|c|c|}
\hline Factor Loading & LPM & PLM & SP & SRD \\
\hline PLM1 & & 0.864 & & \\
\hline PLM2 & & 0.872 & & \\
\hline PLM3 & & 0.862 & & \\
\hline SP1 & & & 0.873 & \\
\hline SP2 & & & 0.864 & \\
\hline SP3 & & & 0.948 & \\
\hline SP4 & & & 0.916 & \\
\hline SRD1 & & & & 0.869 \\
\hline SRD2 & & & & 0.908 \\
\hline SRD3 & & & & 0.909 \\
\hline
\end{tabular}

Convergent validity test reflexive indicators with Smart PLS 3.0 program conducted by the researchers to be able to see the value of the loading factor for each indicator constructs. Rule of Thumb is usually used to assess the validity of convergent i.e., the loading factor value $(>0.60-0.70)$ for exploratory research is still acceptable when the Average Variance Extracted (AVE) (>0.50) (Chin, 1998; Hair et al., 2012; Wang et al., 2010). The entire value of factor loading in this research is more than 0.70 .

We analyse that PLM2; SRD3 (Provide knowledge about the tools (tools) required to implement Lean Manufacturing and adequate training to employees-worker in the company (Support Worker Principles); The emergence of provider-oriented architecture for information sharing and clarity and reliability reports have important impact on Sustainability Performance as shown in Table III. The Researchers tried to analyse the results of the model when the exogenous variables have an effect on the dependent variable, with other exogenous variables, it is to be an indirect effect. The researchers found specific indicators to analyse the total effects of exogenous variables specifically by adding direct and indirect effects. One variable may have no direct effect, but it may have an indirect effect as well. Researchers analysed for T Statistics PLM $\rightarrow$ SRD $\rightarrow$ SP (3.484) $>1.96$ gave significant effect on SP. In this study, measurements and modelling made by making multiplication between exogenous and moderator variable indicators to form interaction constructs.

The researcher found that, there is a positive significant effect relationship between product life cycle management practices (PLM) and sustainability performance (SP) mediated by disclosure of sustainability report (DSR).

The researcher examined and evaluated the measurement model or outer model for this case by examining valid and reliable. Researcher uses 500 resampling numbers in the bootstrapping process.

\section{CONCLUSION}

This study aims to look at the effects of disclosure sustainability report seen from the economic, environmental dimension, and social dimensions of corporate performance. Based on the results of hypothesis testing, of the three independent variables (economic dimension, the dimension of environmental and social dimensions) of sustainability report disclosure, stakeholders in this research, investors need transparent information related to the economic performance of the company as a consideration before making investment decisions. The good sustainability performance will be beneficial for investor accomplish profitable investments. Disclosure sustainability reviews definitely would affect the cost of the organization through economic, environmental and operational. In preceding studies, showed the disclosure of sustainability report of the environmental dimension has a 
significant positive impact on firm's price. Hence, with high company value, reflects the company has a high marketplace price, which means the performance of the agency deemed improving in the eye of investors. Participation is one form of company responsibility to the surroundings in which the employer operates. In this research, the researchers have concluded that Pulp and Paper Industry in Indonesia has provided knowledge about the tools (tools) required to implement Lean Manufacturing and adequate training to employees-worker in pulp and paper industry (Support Worker Principles). The emergence of provider-oriented architecture for information sharing through reliable reports has an important impact on Sustainability Performance in this research. Finding reveal, a phenomenon with role of sustainability report disclosure has significant effects on Product Lifecycle Management practices towards enhancing sustainability performance.

The disclosure of sustainability report has been found to enhance the firm's capabilities in providing transparent information that would increase the level of confident among investors and other stakeholders. Hence, the productivity of the firm has been increasing due to the higher confidence level and high job satisfaction among the employees. This is mainly because all transactions and events in the firm has been revealed publicly and thus, create a sense of responsibility by the management to perform its duties to satisfy the needs and requirements of the stakeholders. The external environment (politics, economics, social, technology, legal and environment) as well as internal environment of the organization has been taken into consideration by the management of the firms due to the disclosure of the sustainability report has been found in this research.

\section{ACKNOWLEDGEMENTS}

An appreciation given to the Asosiasi Pulpa dan Kertas Indonesia and Supply Chain of Indonesia for their secondary data support and wish to acknowledge Widyatama Foundation for the financial support.

\section{REFERENCES}

Alpenberg, J., \& Scarbrough, D. P. (2016). Exploring communication practices in lean production. Journal of Business Research, 69(11), 4959-4963.

Budiman, F., \& Supatmi. (2009). Pengaruh pengumuman Indonesia Sustainability Reporting Award (ISRA) terhadap abnormal return dan volume perdagangan saham (Studi kasus pada perusahaan ISRA periode 2005-2008). http://stiepena.ac.id/wp-content/uploads/2011/11/Sustainability-ReportingAward.pdf.

Chin, W. W. (1998). The partial least squares approach to structural equation modeling. Modern Methods for Business Research, 295(2), 295-336.

Duque Ciceri, N., Garetti, M., \& Terzi, S. (2009). Product lifecycle management approach for sustainability. In 19th CIRP Design Conference-Competitive Design, pp. 147-54.

Eigner, M., Dickopf, T., \& Apostolov, H. (2017). System lifecycle management-An approach for developing cybertronic systems in consideration of sustainability aspects. Procedia CIRP, 61, 128-133. Elkington, J. (1997). Cannibals with folks: The triple bottom line of 21 st century business. Capstone. Fogliasso, C. E., \& Deeds, B. (2012). The global reporting initiative. Business Journal for Entrepreneurs, 2012(2), 160-175.

Fornell, C., \& Larcker, D. F. (1981). Structural equation models with unobservable variables and measurement error: Algebra and statistics. Journal of Marketing Research, 18(3), 382-388.

Freeman, R. E. (2010). Strategic management: A stakeholder approach. Cambridge University Press.

Freund, A. (2005). Work attitudes of social workers across three sectors of welfare organizations: Public, for-profit, and third sector. Journal of Social Service Research, 31(3), 69-92.

Global Reporting Initiative (GRI). (2016a). GRI 103: Management approach 2016. https:// www.globalreporting.org/standards/media/1038/gri-103-management-approach-2016.pdf.

Global Reporting Initiative (GRI). (2016b). GRI 101: Foundation. https://www.globalreporting.org/ standards/media/1036/gri-101-foundation-2016.pdf.

Govindan, K., Azevedo, S. G., Carvalho, H., \& Cruz-Machado, V. (2014). Impact of supply chain management practices on sustainability. Journal of Cleaner Production, 85, 212-225.

Gritten, D., \& Kant, P. (2007). Assessing the impact of environmental campaigns against the activities of a pulp and paper company in Indonesia. International Forestry Review, 9(4), 819-834.

Hair, J. F., Sarstedt, M., Ringle, C. M., \& Mena, J. A. (2012). An assessment of the use of partial least 
squares structural equation modeling in marketing research. Journal of the Academy of Marketing Science, 40(3), 414-433.

Hajmohammad, S., Vachon, S., Klassen, R. D., \& Gavronski, I. (2013). Reprint of Lean management and supply management: Their role in green practices and performance. Journal of Cleaner Production, 56, 86-93.

Labuschagne, C., Brent, A. C., \& Van Erck, R. P. (2005). Assessing the sustainability performances of industries. Journal of Cleaner Production, 13(4), 373-385.

Lee, Y. J., \& Sabharwal, M. (2016). Education-job match, salary, and job satisfaction across the public, non-profit, and for-profit sectors: Survey of recent college graduates. Public Management Review, 18(1), 40-64.

Lozano, R., Nummert, B., \& Ceulemans, K. (2016). Elucidating the relationship between sustainability reporting and organisational change management for sustainability. Journal of Cleaner Production, 125, 168-188.

Milne, M. J., \& Gray, R. (2013). W (h) ither ecology? The triple bottom line, the global reporting initiative, and corporate sustainability reporting. Journal of Business Ethics, 118(1), 13-29.

Mukherjee, I., \& Sovacool, B. K. (2014). Palm oil-based biofuels and sustainability in Southeast Asia: A review of Indonesia, Malaysia, and Thailand. Renewable and Sustainable Energy Reviews, 37, 1-12.

Ngoc, U. N., \& Schnitzer, H. (2009). Sustainable solutions for solid waste management in Southeast Asian countries. Waste Management, 29(6), 1982-1995.

Piercy, N., \& Rich, N. (2015). The relationship between lean operations and sustainable operations. International Journal of Operations and Production Management, 35(2), 282-315.

Sawani, Y., Mohamed Zain, M., \& Darus, F. (2010). Preliminary insights on sustainability reporting and assurance practices in Malaysia. Social Responsibility Journal, 6(4), 627-645.

Seuring, S., \& Gold, S. (2013). Sustainability management beyond corporate boundaries: From stakeholders to performance. Journal of Cleaner Production, 56, 1-6.

Srinivasan, V. (2011). An integration framework for product lifecycle management. Computer-Aided Design, 43(5), 464-478.

Tarigan, J., \& Semuel, H. (2015). Pengungkapan sustainability report dan kinerja keuangan. Jurnal Akuntansi dan Keuangan, 16(2), 88-101.

Vila, C., Abellán-Nebot, J. V., Albiñana, J. C., \& Hernández, G. (2015). An approach to sustainable product lifecycle management (Green PLM). Procedia Engineering, 132, 585-592.

Wang, H., Henseler, J., Vinzi, V. E., \& Chin, W. W. (2010). Handbook of partial least squares: Concepts, methods and applications. Springer.

Zhang, H., Ouzrout, Y., Bouras, A., \& Savino, M. M. (2014). Sustainability consideration within product lifecycle management through maturity models analysis. International Journal of Services and Operations Management, 19(2), 151-171. 